\title{
Article \\ Mycorrhizal Inoculation Improves Plant Growth and Yield of Micropropagated Early Globe Artichoke under Field Conditions
}

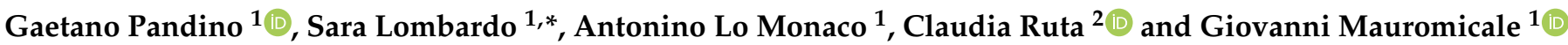 \\ 1 Dipartimento di Agricoltura, Alimentazione e Ambiente (Di3A), Università degli Studi di Catania, \\ Via Valdisavoia 5, 95123 Catania, Italy; g.pandino@unict.it (G.P.); lomonaco.antonino@libero.it (L.M.A.); \\ g.mauromicale@unict.it (G.M.) \\ 2 Dipartimento di Scienze Agro Ambientali e Territoriali (DiSAAT), Università degli Studi di Bari, \\ Via G. Amendola 165, 70126 Bari, Italy; claudia.ruta@uniba.it \\ * Correspondence: sara.lombardo@unict.it; Tel.: +39-0954783421
}

check for updates

Citation: Pandino, G.; Lombardo, S.; Lo Monaco, A.; Ruta, C.; Mauromicale, G. Mycorrhizal Inoculation Improves Plant Growth and Yield of Micropropagated Early Globe Artichoke under Field Conditions. Agriculture 2022, 12, 114. https://doi.org/10.3390/ agriculture12010114

Academic Editor: Peter A. Roussos

Received: 20 December 2021

Accepted: 11 January 2022

Published: 14 January 2022

Publisher's Note: MDPI stays neutral with regard to jurisdictional claims in published maps and institutional affiliations.

Copyright: (C) 2022 by the authors. Licensee MDPI, Basel, Switzerland. This article is an open access article distributed under the terms and conditions of the Creative Commons Attribution (CC BY) license (https:/ / creativecommons.org/licenses/by/ $4.0 /)$.

\begin{abstract}
The micropropagation appears to be a valid alternative method for the production of largescale, phenotypically homogeneous, and disease-free plants, particularly for spring globe artichoke genotypes. Nevertheless, micropropagated plants have some problems during the acclimatization in field environments. The inoculation with arbuscular mycorrhizal fungi appeared to overcome the transplanting stress. Therefore, a comparison was drawn between the field performances of different vegetative propagation techniques (micropropagated/mycorrhized and offshoots cultivation) of early globe artichoke clones over two growing seasons. The micropropagation/mycorrhization appeared to deliver a better field performance in terms of both plant growth and productivity traits as compared with offshoots cultivated. In particular, the micropopagated/mycorrhized plants exhibited the highest vegetative growth values than the offshoots of the cultivated ones, such as the plant height and the main floral stem length. The micropopagated/mycorrhized plants were also more productive, exceeding the head yield of offshoots cultivated ones by about $63 \%$. However, the micropopagated/mycorrhized plants accumulated almost a month late on the first harvest respect to offshoots cultivated ones. Our data also showed that the effects of the new proposed propagation method were genotype- and season-dependent. Accordingly, some plant growth and productivity traits showed significant 'propagation method $\times$ genotype' and 'propagation method $\times$ growing season' interaction. This study revealed that the micropropagation, as well as the mycorrhization, could represent an efficient and sustainable cropping system to reintroduce and increase the productivity of autochthons landraces.
\end{abstract}

Keywords: Cynara cardunculus L.; propagation method; genotype; season; sustainable cropping; yield

\section{Introduction}

The Cynara cardunculus complex includes three recognized taxa, all native to the Mediterranean Basin, including the globe artichoke (var. scolymus), the cultivated cardoon (var. altilis), and the wild cardoon (var. sylvestris). The globe artichoke is recognized to represent a multi-purpose crop, since it is suitable for both food applications and medicinal purposes [1], due its abundance of polyphenols, inulin, minerals and other compounds [2-4]. In Italy, the leading world producer, the globe artichoke cultivation is based on just a few autochthonous landraces and has been an important component of rural economic stability and social development in the southern districts, such as Apulia, Sardinia and Sicily [5]. In Sicily, the production was totally characterized by the autochthonous landraces 'Spinoso di Palermo' and 'Violetto di Sicilia', thanks largely to their early flowering habit and acceptability to consumers, and kept over centuries by local farmers via vegetative propagation [6]. As suggested by Portis et al. [7], this allowed accumulating a lot of mutations, responsible for unreliable yield potential and variability in head traits of autochthonous landraces. As consequence, the farmers' choice was oriented in the introduction of commercial genotypes, 
more productive and homogenous, leading to recognize the autochthonous landraces at risk of genetic depletion. On the other hand, the variability in head traits has allowed, through a program of clonal selection, to improve yield and re-establish morphological homogeneity of the local germplasm, offering well-defined clones to growers [8,9]. The main disadvantage of the vegetative propagation is to do not ensure virus-free plantlets, which could strongly affect the total yield. Currently, the micropropagation appears to be a valid alternative method to produce large-scale, phenotypically homogeneous and disease-free plants, and to provide propagation material to farmers $[10,11]$. Nowadays, this propagation technique has had success in late genotypes such as 'Romanesco type', obtaining phenotypically homogeneous plantles and improved field performance [12-14], In early globe artichoke genotypes, an effective protocol has yet to be found, since it caused the loss of precocity [15] s. In the meantime, the micropropagation shows several morpho-physiological problems during the acclimatization in open-field environments. Consequently, a substantial number of micropropagated plants do not survive the transfer from in vitro to ex vitro conditions [16]. Several attempts have tried to define the most appropriate technique to facilitate the acclimatization in ex vitro conditions of globe artichoke material, mainly by inoculation with arbuscular mycorrhizal fungi (AMF) $[10,17,18]$. AMF are the most important microbial symbioses living in intimate association with the roots of most crop and horticultural plants species worldwide. Numerous studies provided positive effects of AMF symbiosis on plant growth, water uptake, nutrition uptake, tolerance to environmental stressors (drought, salt, heavy metal pollution, soil pathogens) and above-ground productivity. They also act as bioprotectants against pathogens and toxic stresses [19-21]. Most studies were conducted under controlled conditions [22,23], but the behavior of inoculated plants after transplantation in open fields received little attention, although it is known that the efficiency of the AMF application depended upon genotype and environmental conditions [24,25]. Recently, we reported as the micropropagation, in conjunction with the mycorrhizal inoculation, may represent an efficient and sustainable strategy to improve plant phenolic compounds in globe artichoke plants [26]. In the present work, our hypothesis was to evaluate the effectiveness (if any) of the micropropagation, along with the mycorrhization, as novel propagation technique to improve the productive performance in field conditions, such as modernize the traditional vegetative propagation of the globe artichoke by 'ovoli', 'offshoots', stumps, etc. In this view a two seasons experiment was designed to evaluate the plant growth and the productive traits of three new early clones of 'Violetto di Sicilia' globe artichoke.

\section{Materials and Methods}

\subsection{In Vitro Culture of Globe Artichoke Explants}

The globe artichoke plantlets of three new early clones of 'Violetto di Sicilia' were obtained by in vitro micropropagation from offshoots explants following the protocol described by Pandino et al. [26]. Briefly, 15 offshoots were picked up from each mother plant, and shoot tips (5-6 mm in length) were cut off to obtain primary explants. They were sterilized by immersion in $70 \%$ ethanol $(v / v)$ for $1 \mathrm{~min}$ followed by $0.05 \%$ mercuric chloride solution for $15 \mathrm{~min}$ and cleaned three times with sterile distilled water. The explants were moved into $70 \mathrm{~mL}$ glass tubes containing $20 \mathrm{~mL}$ of basal medium (BM) supplemented with 6- $\left(\gamma, \gamma\right.$-dimethylallylamino)purine (2iP) $\left(1 \mathrm{mg} \mathrm{L}^{-1}\right)$, indoleacetic acid (IAA) $\left(1 \mathrm{mg} \mathrm{L}^{-1}\right)$ and gibberellic acid (GA3) (0.025 $\mathrm{mg} \mathrm{L}^{-1}$ ) to set up the in vitro conditions proposed by Morone Fortunato et al. [10]. The basal medium was composed by Murashige and Skoog [27] macronutrients, Nitsch and Nitsch [28] micronutrients, Ferric EDTA (30 $\left.\mathrm{mg} \mathrm{L}^{-1}\right)$, thiamine $\mathrm{HCl}\left(0.4 \mathrm{mg} \mathrm{L}^{-1}\right)$, myoinositol $\left(100 \mathrm{mg} \mathrm{L}^{-1}\right)$, agar $\left(7 \mathrm{~g} \mathrm{~L}^{-1}\right)$ and sucrose $\left(20 \mathrm{~g} \mathrm{~L}^{-1}\right)$. After 21 days, the shoots were moved into $200 \mathrm{~mL}$ glass vessels containing $40 \mathrm{~mL}$ of proliferation medium constituted by BM and $0.05 \mathrm{mg} \mathrm{L}^{-1}$ 6-benzylaminopurine (BAP) and subcultured three times each 25 days [10]. The grown shoots were rooted for one month in the same kind of glass vessels containing $40 \mathrm{~mL}$ of BM added with a higher sucrose concentration (30 $\left.\mathrm{g} \mathrm{L}^{-1}\right)$ and supplemented with IAA $\left(10 \mathrm{mg} \mathrm{L}^{-1}\right)$ [10]. The explants were multiplied 
and rooted for one month in glass vessels located in a growth chamber at $22 \pm 2{ }^{\circ} \mathrm{C}$, a photoperiod of $16 \mathrm{~h}$ light, a light intensity of $60 \mu \mathrm{Em}^{-2} \mathrm{~s}^{-1}$ and containing the culture media selected by Morone Fortunato et al. [10]. At the time of transplant, for each clone, 40 uniform rooted microplants were inoculated with $10 \mathrm{~g}$ of crude arbuscular mycorrhiza (AM) fungus inoculum of Glomus viscosum H.T. Nicolson (syn. Septoglomus viscosum). The inoculum was applyed below the root system filled with sterilized commercial peat mixture enriched with nutrients (organic carbon $46 \%$, organic nitrogen 1-2\%, and organic matter $80 \%$ ) and mixed with perlite at a 2:1 $(v / v)$ ratio. Acclimatization occurred at the University of Bari "Aldo Moro", Apulia, Italy $\left(41^{\circ} 7^{\prime} 31^{\prime \prime} \mathrm{N}, 16^{\circ} 52^{\prime} 0^{\prime \prime} \mathrm{E}\right)$ in greenhouse condition at $20-25{ }^{\circ} \mathrm{C}$ with mist, reducing the humidity level from $85-90 \%$ to $55-60 \%$ over 20 days (Figure 1). Percentage of AM colonized root length was evaluated on randomly collected $30 \mathrm{~g}$ of root samples, after root staining, by using the method proposed by Giovannetti and Mosse [29]. Percentage mycorrhizal colonization and mycorrhizal dependency were also quantified. according to Ruta et al. [30].

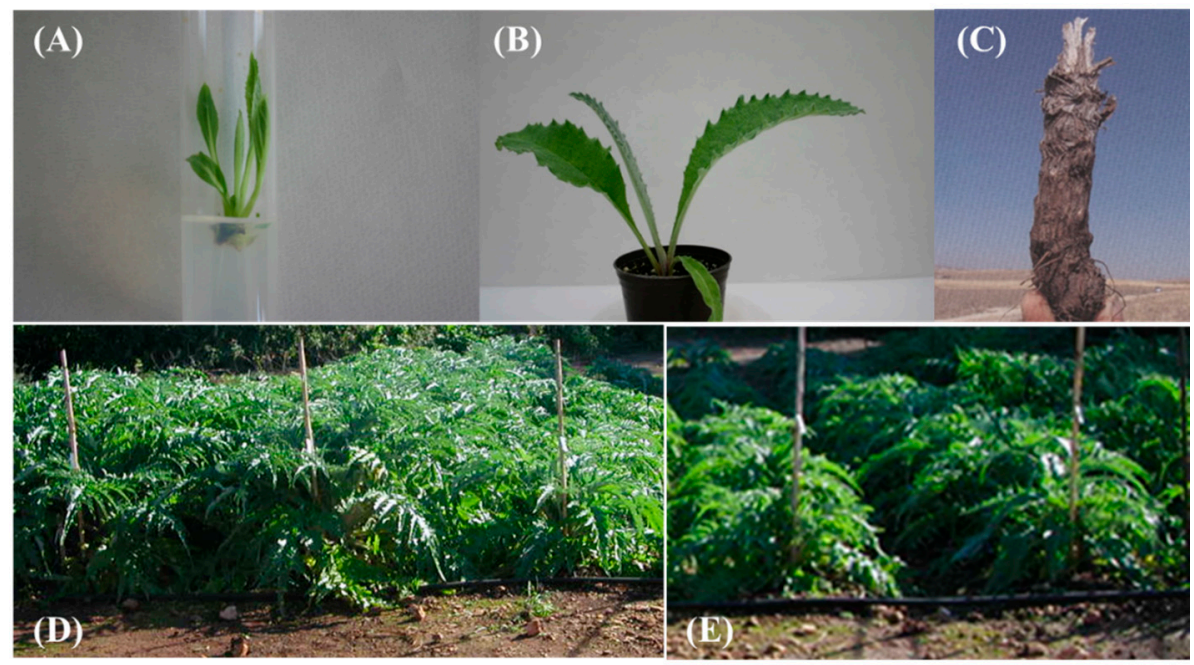

Figure 1. In vitro establishment (A) and acclimatization (B) of micropropagated plants, pre-sprouted 'ovoli' (C), micropropagated/mycorrhized (D) and offshoots cultivated plants in field conditions (E).

\subsection{Experimental Field and Plant Material}

A two-year experiment was carried out during 2011/2012 (season I) and 2012/2013 (season II) on the coastal plain of Cassibile (SR) $\left(36^{\circ} 58^{\prime} \mathrm{N} ; 15^{\circ} 11^{\prime} \mathrm{E} ; 53 \mathrm{~m}\right.$ a.s.1.), a typical area for globe artichoke cultivation in Italy. The local climate is semi-arid Mediterranean, with mild winters, and hot, dry summers. Soil characteristics were as follows: 35\% clay, 18\% silt and 47\% sand; pH 7.7; organic matter 1.1\%; total nitrogen $0.10 \% ; \mathrm{P}_{2} \mathrm{O}_{5}$ available $0.008 \%$; $\mathrm{K}_{2} \mathrm{O}$ exchangeable $0.091 \%$. The field capacity at $-0.03 \mathrm{MPa}$ was $0.28 \mathrm{~g} \mathrm{~g}^{-1} \mathrm{dry}$ weight; the wilting point at $-1.5 \mathrm{MPa}$ was $0.15 \mathrm{~g} \mathrm{~g}^{-1}$ dry weight; bulk density was $1.22 \mathrm{~g} \mathrm{~m}^{-3}$. The previous crop was potato. A split plot experimental design, with four replicates, was arranged to test the effects of season, as mean plot, the micropropagation/mycorrhization propagation technique, compared with vegetative propagation traditionally carried out by 'ovoli' (semi-dormant offshoots) in the Mediterranean Basin as sub-plots, on three new early globe artichoke clones of 'Violetto di Sicilia' ('C1', 'C2' and 'C3') as sub-sub-plots. The clones were selected on the basis of earliness, total yield, and capitulum quality (color of the external bracts, shape, size and consistency), in agreement with a previous study [7]. Micropropagated plants with 3-4 leaves and pre-sprouted 'ovoli', collected during summer when the aerial part of the mother plant is dried [31], were transplanted in August 2011 (Figure 1). Each plot consisted of 16 plants at $0.8 \mathrm{~m}$ apart within a row and $1.2 \mathrm{~m}$ apart among close rows, adopting a plant density of 1.0 plant $\mathrm{m}^{-2}$. In the second season, plant regrowth was stimulated by applying drip irrigation to field capacity in early September 2012. On both seasons, a typical fertilizer regime $\left(80 \mathrm{~kg}\right.$ of $\mathrm{N}$ as ammonium nitrate, $80 \mathrm{~kg}$ of $\mathrm{P}_{2} \mathrm{O}_{5}$ as triple sulfate phosphate, and $100 \mathrm{~kg}$ of $\mathrm{K}_{2} \mathrm{O}$, as potassium sulfate, per ha) was applied 
before planting (Season I) or crop regrowth (Season II). In both seasons, two additional $\mathrm{N}$ application (as ammonium nitrate) were applied in early November and January. The drip irrigation was supplied by restituting $100 \%$ of maximum evapotranspiration, when accumulated daily evaporation, net of rain (measured from an unscreened class A-pan evaporimeter about $50 \mathrm{~m}$ of the crop), reached $40 \mathrm{~mm}$ (corresponding to about 0.50 of available soil water content at a depth of $0.30 \mathrm{~m}$ ). The weed and pest control was performed according to the standard local commercial practice. Giberellic acid was not supplied to the plants during the crop cycle, to promote earliness of capitula ripening. Lateral offshoots were manually removed two times (late September and January), leaving only one shoot per plant.

\subsection{Morphological and Bio-Agronomical Characterization}

At the end of each cropping season, on 10 plants per propagation technique, genotype and replicate, collected in the experimental field excluding the border lines, the following variables were calculated: days to first harvest (DFH), as the number of days between transplanting (Season I) or awakening (Season II) and the harvest of the main head; duration of harvest period (DHP), as the number of days elapsed from first to last harvest; number of heads per plant $(\mathrm{NH})$; yield $(\mathrm{Y})$ expressed as $\mathrm{kg}$ heads per plant. At the first harvest, plant height, main floral stem length, as the height from base to central flower head, diameter main floral stem, length and width of longest lobe leaf were evaluated. Heads were collected at usual marketing stage (stage D) [26] and severed from floral stems in order to determine the following traits: main head fresh weight (WM); first order head fresh weight (WF); second order head fresh weight (WS); and third order head fresh weight (WT).

\subsection{Meteorological Trend}

During the two-year experiments, daily temperature and rainfall were measured by a meteorological station located about $150 \mathrm{~m}$ of the field. The total rainfall in season I fell mostly between September and February (856 out of $944 \mathrm{~mm}$ ), while season II was rather unusual, since the rainfall amount was low $(502 \mathrm{~mm})$, and $70 \%$ of it fell between September and November (Figure 2). Except in December, the higher mean maxima temperatures were recorded in the season $\mathrm{II}$ than in the season $\mathrm{I}$, as well the lower mean minima temperature in December (6.9 vs. $8.2^{\circ} \mathrm{C}$ ) (Figure 2$)$.

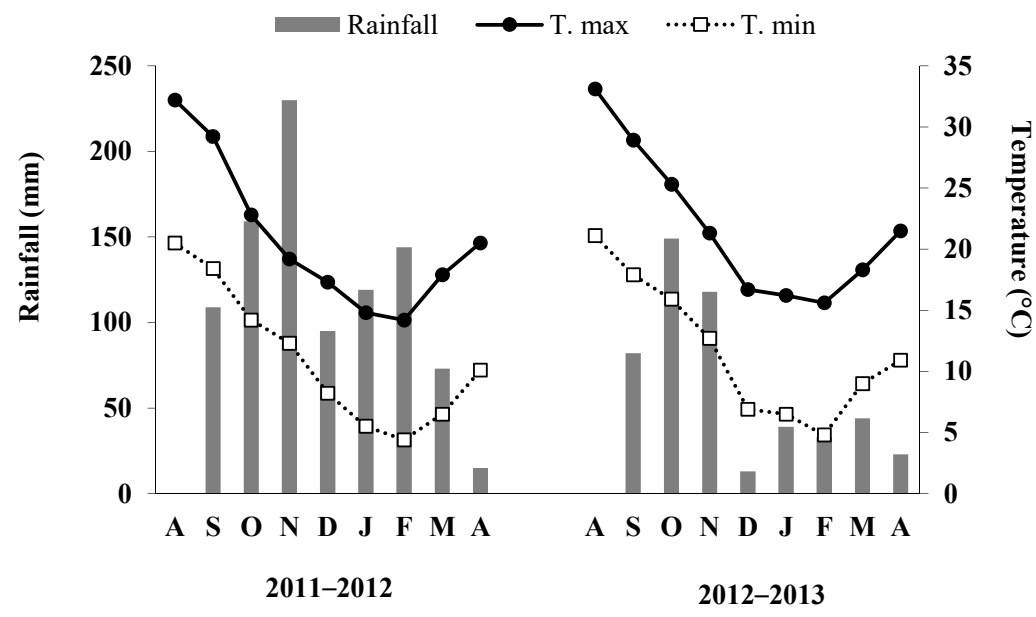

Figure 2. Total rainfall, mean monthly maxima and minima temperatures at the experimental site during 2011-2013.

\subsection{Statistical Analysis}

Bartlett's test was chosen to assess for homoscedasticity, and then the data were subjected to a three-way analysis of variance (ANOVA), based on a factorial combination of 'season $(2) \times$ propagation method $(2) \times$ genotype $(3)$ '. Means were separated by least significant difference (LSD) test when the F-test was significant. Statistical analysis was 
performed using the CoStat ${ }^{\circledR}$ computer package version 6.003 (CoHort Software, Monterey, CA, USA).

\section{Results}

\subsection{Plant Growth Responses and Mycorrhizal Colonization}

The micropropagation protocol proved to be efficient, with a good multiplication index of the initial explant placed in culture ( 14 shoots at the third subculture) and excellent results in terms of rooting, obtaining morphologically complete seedlings, with well-developed root system for about $88 \%$ of sprouts reared in vitro.

This data was validated by the analysis of symbiotic parameters, evaluated three months after the ex-vitro setting, which showed a higher percentage of infection $(79 \%)$ and mycorrhizal dependence (59\%) in plants inoculated with G.viscosum.

\subsection{Morphological Characterization of Plant}

Here, differences in the considered UPOV descriptors were observed by comparing offshoots cultivated and micropropagated/mycorrhized planting material of three new early globe artichoke clones (Table 1 ). The ANOVA test revealed that the propagation method represented the main factor affecting all UPOV descriptors undertaken, explaining over $90 \%$ of the total variance for four out of the five morphological traits (Table 1). The micropopagated/mycorrhized plants exhibited the highest vegetative growth values. In facts, they, respect to offshoots cultivation ones showed the highest plant height (158 vs. $94 \mathrm{~cm}$ ), and the main floral stem length ( 34.1 vs. 28.8$)$ respect to offshoots cultivated ones.

Table 1. Mean square per each source of variation (percentage of total) resulting from analysis of variance.

\begin{tabular}{|c|c|c|c|c|c|c|}
\hline \multirow[b]{2}{*}{ Parameter } & \multicolumn{6}{|c|}{ Source of Variation } \\
\hline & $\begin{array}{c}\text { Genotype } \\
\text { (G) }\end{array}$ & $\begin{array}{l}\text { Propagation } \\
\text { Method (PM) }\end{array}$ & Season (S) & $\mathbf{G} \times \mathbf{P M}$ & $\mathbf{G} \times \mathbf{S}$ & $\mathbf{P M} \times \mathbf{S}$ \\
\hline Plant height & $1.2 * * *$ & $93.8^{* * *}$ & ns & $3.6^{* * *}$ & ns & ns \\
\hline Main floral stem length & $18.9^{* * *}$ & $45.3^{* * *}$ & ns & $34.8^{* * *}$ & ns & ns \\
\hline Main floral stem diameter & ns & $97.6^{* * *}$ & ns & ns & ns & ns \\
\hline Leaf length of longest lobe & $2.1 * * *$ & $92.0 * * *$ & ns & ns & ns & ns \\
\hline Leaf width of longest lobe & $6.2 * * *$ & $90.2^{* * *}$ & ns & ns & ns & ns \\
\hline First harvest & $6.1^{* * *}$ & $29.1^{* * *}$ & $57.0^{* * *}$ & $3.6^{* * *}$ & ns & ns \\
\hline Harvest period & $25.3^{* * *}$ & $23.3^{* * *}$ & $22.7^{* * *}$ & $17.0 * *$ & ns & ns \\
\hline Number of heads & ns & $68.5^{* * *}$ & $25.9^{* * *}$ & ns & ns & $4.1^{* * *}$ \\
\hline Fresh weight yield & ns & $76.0^{* * *}$ & $21.1^{* * *}$ & ns & ns & ns \\
\hline Main head fresh weight & $4.2 * * *$ & $85.2^{* * *}$ & ns & $8.9^{* * *}$ & $\mathrm{~ns}$ & ns \\
\hline First order head fresh weight & $8.1^{* * *}$ & $51.9^{* * *}$ & $20.2^{* * *}$ & $5.7^{* *}$ & ns & $9.0 * *$ \\
\hline Second order head fresh weight & $22.2^{* * *}$ & $38.3^{* * *}$ & $11.8^{* * *}$ & $20.2 * * *$ & ns & $4.2 *$ \\
\hline Third order head fresh weight & $2.3^{* * *}$ & $96.8^{* * *}$ & ns & ns & ns & $\mathrm{ns}$ \\
\hline Degree of freedom & 2 & 1 & 1 & 2 & 2 & 1 \\
\hline
\end{tabular}

$* * *, * * * *$ indicate significant at $p \leq 0.001, p \leq 0.01$ and $p \leq 0.05 ;$ ns: not significant.

Except for the main floral stem diameter, significant differences among clones were also observed. ' $\mathrm{C} 1$ ' recorded the greatest length and width of leaf longest lobe respect to both ' $\mathrm{C} 2$ ' and ' $\mathrm{C} 3$ '. On the contrary, ' $\mathrm{C} 3$ ' was characterized by the highest plant height and main floral stem length (Table 2).

The latter morphological traits have also showed significant 'genotype $\times$ propagation method' interaction (Table 2). In particular, the micropopagated/mycorrhized clones reported the highest and lowest main floral stem length, with values of 39.4 ('C3') and $26.3 \mathrm{~cm}\left({ }^{\prime} \mathrm{C} 1^{\prime}\right)$, respectively, respect to offshoots cultivated ones (Figure 3A). On the other hand, an effect of micropropagation, in conjunction with the provision of mycorrhiza, was to induce a rise in the plant height of the plants, achieving the maximum increase in ' $\mathrm{C} 2$ ' $(+53 \%)$ (Figure 3B). 
Table 2. Morphological characterization of the selected globe artichoke genotypes ( \pm standard deviation) as affected by main factors under study. Different letters within the same parameter and main factor show significant differences among means (LSD test, $p<0.05$ ).

\begin{tabular}{|c|c|c|c|c|c|}
\hline \multirow[b]{2}{*}{ Source of Variation } & \multicolumn{3}{|c|}{ Plant } & \multicolumn{2}{|c|}{ Leaf } \\
\hline & $\begin{array}{l}\text { Plant Height } \\
\text { (cm) }\end{array}$ & $\begin{array}{l}\text { Main Floral } \\
\text { Stem Length } \\
\quad(\mathrm{cm})^{1}\end{array}$ & $\begin{array}{c}\text { Main Floral } \\
\text { Stem Diameter } \\
(\mathrm{cm})\end{array}$ & $\begin{array}{c}\begin{array}{c}\text { Length of } \\
\text { Longest Lobe } \\
(\mathrm{cm})\end{array}\end{array}$ & $\begin{array}{c}\text { Width of } \\
\text { Longest Lobe } \\
\text { (cm) }\end{array}$ \\
\hline \multirow{2}{*}{\multicolumn{6}{|c|}{$\begin{array}{l}\text { Propagation method } \\
\text { offshoots cultivation } \\
\text { micropropagation/ } \\
\text { mycorrhization } \\
\text { Genotype }\end{array}$}} \\
\hline & & & & & \\
\hline $\mathrm{C} 1$ & $119.9 \pm 4.3 \mathrm{~b}$ & $28.3 \pm 2.0 \mathrm{c}$ & $2.6 \pm 0.3$ & $10.7 \pm 0.1 \mathrm{a}$ & $6.4 \pm 0.3 \mathrm{a}$ \\
\hline $\mathrm{C} 2$ & $122.0 \pm 4.2 \mathrm{~b}$ & $32.1 \pm 1.1 \mathrm{~b}$ & $2.7 \pm 0.3$ & $10.1 \pm 0.2 c$ & $5.6 \pm 0.2 \mathrm{~b}$ \\
\hline $\mathrm{C} 3$ & $135.6 \pm 3.1 \mathrm{a}$ & $34.0 \pm 0.8 \mathrm{a}$ & $2.6 \pm 0.4$ & $10.3 \pm 0.2 b$ & $5.6 \pm 0.2 \mathrm{~b}$ \\
\hline \multicolumn{6}{|l|}{ Season } \\
\hline I & $124.7 \pm 3.2$ & $31.1 \pm 2.5$ & $2.6 \pm 0.3$ & $10.2 \pm 0.4$ & $5.8 \pm 0.1$ \\
\hline II & $127.0 \pm 3.2$ & $31.8 \pm 2.2$ & $2.7 \pm 0.4$ & $10.8 \pm 0.3$ & $6.0 \pm 0.2$ \\
\hline
\end{tabular}

${ }^{1}$ Height from base to central flower head; I: 2011-2012; II: 2012-2013.
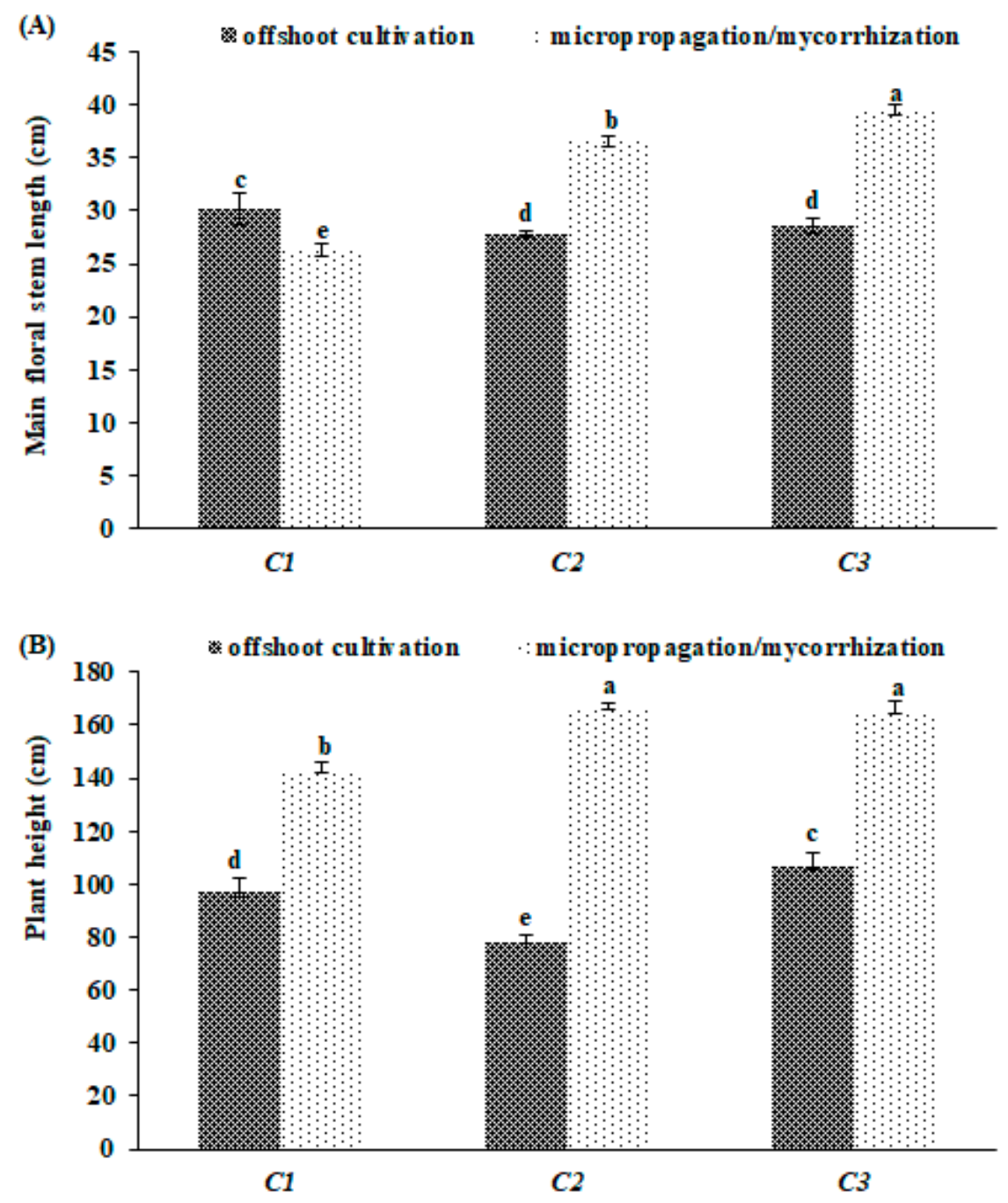

Figure 3. Main floral stem length (A) and plant height (B) in clone of globe artichoke plants as affected by 'genotype $\times$ propagation method'. Different letters indicate significance at Fisher's protected LSD (least significant difference) test $(p \leq 0.05)$. Vertical bars indicate \pm standard deviation. 


\subsection{Bio-Agronomical Characterization of Plant}

As observed for the morphological traits, the propagation method was the main factor affecting for all of the bio-agronomical traits, excluding the DHP (days to first harvest) (Table 1). In particular, for five out of the eight bio-agronomical traits the propagation method explained over $50 \%$ of the total variance (Table 1). Except for the DHP (duration of harvest period), the micropopagated/mycorrhized plants exhibited the highest values of all bio-agronomical considered traits respect to offshoots cultivated ones (Table 3 ). As regard DFH, the micropopagated/mycorrhized plants reported the longest delay (24 days) in producing the first head, but they had a significantly shorter productive period $(\mathrm{DHP}=37$ days) (Table 3$)$. In addition, the micropopagated/mycorrhized plants were proved to be most productive, exceeding the yield of offshoots cultivated ones by about $1 \mathrm{~kg} \mathrm{plant}^{-1}$ (2.1 vs. $1.2 \mathrm{~kg} \mathrm{plant}^{-1}$ ) (Table 3). This result appeared to be congruent with both $\mathrm{NH}$ (number of heads per plant) and head fresh weight [main head fresh weight (WM); first order head fresh weight (WF); second order head fresh weight (WS); third order head fresh weight (WT)], as both traits showed the highest value in the micropopagated/mycorrhized plants (Table 3). These latter were the best performing with 15 heads plant ${ }^{-1}$ (Table 3). Going to head fresh weight, the micropopagated/mycorrhized plants recorded a major weight in both main and lateral head (first, second and third order), ranging from +5 (WS) to $+33 \%$ (WT) in comparison with the offshoots cultivated plants (Table 3).

Table 3. Bio-agronomical characterization of the selected globe artichoke genotypes ( \pm standard deviation) as affected by main factors under study. Different letters within the same parameter and main factor show significant differences among means (LSD test, $p \leq 0.05$ ).

\begin{tabular}{|c|c|c|c|c|c|c|c|c|}
\hline Source of Variation & $\begin{array}{l}\text { DFH } \\
\text { (d) }\end{array}$ & $\begin{array}{l}\text { DHP } \\
\text { (d) }\end{array}$ & $\begin{array}{c}\mathrm{NH} \\
\text { (n Plants } \\
\text { (1) }\end{array}$ & $\begin{array}{c}\mathrm{Y} \\
\left(\mathrm{kg} \mathrm{Plant}^{-1}\right)\end{array}$ & $\begin{array}{l}\text { WM } \\
\text { (g) }\end{array}$ & $\begin{array}{l}\text { WF } \\
\text { (g) }\end{array}$ & $\begin{array}{l}\text { WS } \\
\text { (g) }\end{array}$ & $\begin{array}{l}\text { WT } \\
\text { (g) }\end{array}$ \\
\hline \multicolumn{9}{|l|}{$\begin{array}{l}\text { Propagation method } \\
\text { offshoots cultivation }\end{array}$} \\
\hline $\begin{array}{l}\text { micropropagation/ } \\
\text { mycorrhization } \\
\text { Genotype }\end{array}$ & $207 \pm 6.5 \mathrm{a}$ & $37 \pm 3.3 b$ & $15 \pm 2.1 \mathrm{a}$ & $2.1 \pm 0.3 \mathrm{a}$ & $233.1 \pm 2.6 \mathrm{a}$ & $162.5 \pm 7.9 \mathrm{a}$ & $123.9 \pm 2.9 \mathrm{a}$ & $89.0 \pm 3.5 \mathrm{a}$ \\
\hline $\mathrm{C} 1$ & $187 \pm 2.5 b$ & $48 \pm 4.9 \mathrm{a}$ & $12 \pm 4.1$ & $1.7 \pm 0.6$ & $219.6 \pm 5.6 a$ & $160.2 \pm 1.1 \mathrm{a}$ & $118.9 \pm 3.1$ & $82.0 \pm 1.9 \mathrm{a}$ \\
\hline $\mathrm{C} 2$ & $201 \pm 1.3 \mathrm{a}$ & $33 \pm 3.1 b$ & $12 \pm 3.7$ & $1.7 \pm 0.6$ & $203.2 \pm 1.2 \mathrm{~b}$ & $148.2 \pm 2.0 \mathrm{~b}$ & $125.5 \pm 4.1$ & $77.5 \pm 2.4 \mathrm{~b}$ \\
\hline $\mathrm{C} 3$ & $190 \pm 2.2 \mathrm{~b}$ & $44 \pm 2.9 \mathrm{a}$ & $12 \pm 3.4$ & $1.7 \pm 0.5$ & $212.6 \pm 5.2 \mathrm{a}$ & $146.6 \pm 1.5 \mathrm{~b}$ & $117.9 \pm 3.0$ & $77.3 \pm 2.1 b$ \\
\hline \multicolumn{9}{|l|}{ Season } \\
\hline I & $205 \pm 6.8 \mathrm{a}$ & $37 \pm 4.4 \mathrm{~b}$ & $11 \pm 3.8 \mathrm{~b}$ & $1.5 \pm 0.6 \mathrm{~b}$ & $210.6 \pm 7.7$ & $144.9 \pm 2.5 \mathrm{~b}$ & $119.0 \pm 1.2 b$ & $78.4 \pm 5.5$ \\
\hline II & $185 \pm 3.1 \mathrm{~b}$ & $46 \pm 2.2 \mathrm{a}$ & $14 \pm 2.6 \mathrm{a}$ & $1.9 \pm 0.5 \mathrm{a}$ & $213.1 \pm 5.1$ & $158.4 \pm 1.1 \mathrm{a}$ & $122.5 \pm 1.5 \mathrm{a}$ & $79.4 \pm 6.4$ \\
\hline
\end{tabular}

I, 2011-2012; II, 2012-2013; DFH, first harvest; DHP, harvest period; NH, number of heads; Y, fresh weight yield, WM, main head fresh weight; WF, first order head fresh weight; WS, second order head fresh weight; WT, third order head fresh weight.

Except for the $\mathrm{NH}$ and $\mathrm{Y}$, significant differences among clones were also detected (Table 1). ' $\mathrm{C} 1$ ' and ' $\mathrm{C} 3$ ' revealed similar behaviour for most of the bio-agronomical traits, since they had the highest values of both WM and $\mathrm{DH}$, as well as the lowest ones of WS and DHP respect to 'C2' (Table 3). Furthermore, 'C1' was characterized by significantly higher WF and WT than those of 'C2' and 'C3'.

As for the season effect, only WF and WS showed significant difference between the two growing seasons (Table 1). In particular, both first and second order head reported significantly higher weight in SII, respectively 158 and $122 \mathrm{~g}$, than those harvest in SI (145 and $119 \mathrm{~g}$, respectively) (Table 3).

Five of the considered bio-agronomical traits (DFH, DHP, WM, WF, WS) were also significantly affected by the 'genotype $\times$ propagation method' interaction (Table 1 ).

All of the offshoots cultivated clones recorded the lowest WM in comparison with that of micropopagated/mycorrhized ones (Figure 4A). Same trend was observed for the WF, except for ' $\mathrm{C} 1$ ' (Figure 4B). The offshoots cultivated ' $\mathrm{C} 1$ ' budded the earliest with a DHF, on average, of about 25 days earlier than other clones and 29 days than 
micropopagated/mycorrhized 'C1' (Figure 4D). On the contrary, the offshoots cultivated ' $\mathrm{C} 1$ ' consistently increased its DHP of 21 and 22 days, respectively, with respect to other clones and the micropopagated / mycorrhized ' $\mathrm{C} 1$ ' (Figure 4E). It is worth noting that the DHP proved to be more stable among micropopagated/mycorrhized clones, ranging from 35 ('C2') to 39 days ('C $\left.3^{\prime}\right)$, respect to offshoots cultivated ones, where a major variability was found. For example, about 19 days between the shortest (' $\mathrm{C} 2$ ') and longest productive ('C1') period were detected. Similarly, micropopagated/mycorrhized clones had a wide range regards WS, passing from 117 ('C3') to 133g ('C2') (Figure 4C).
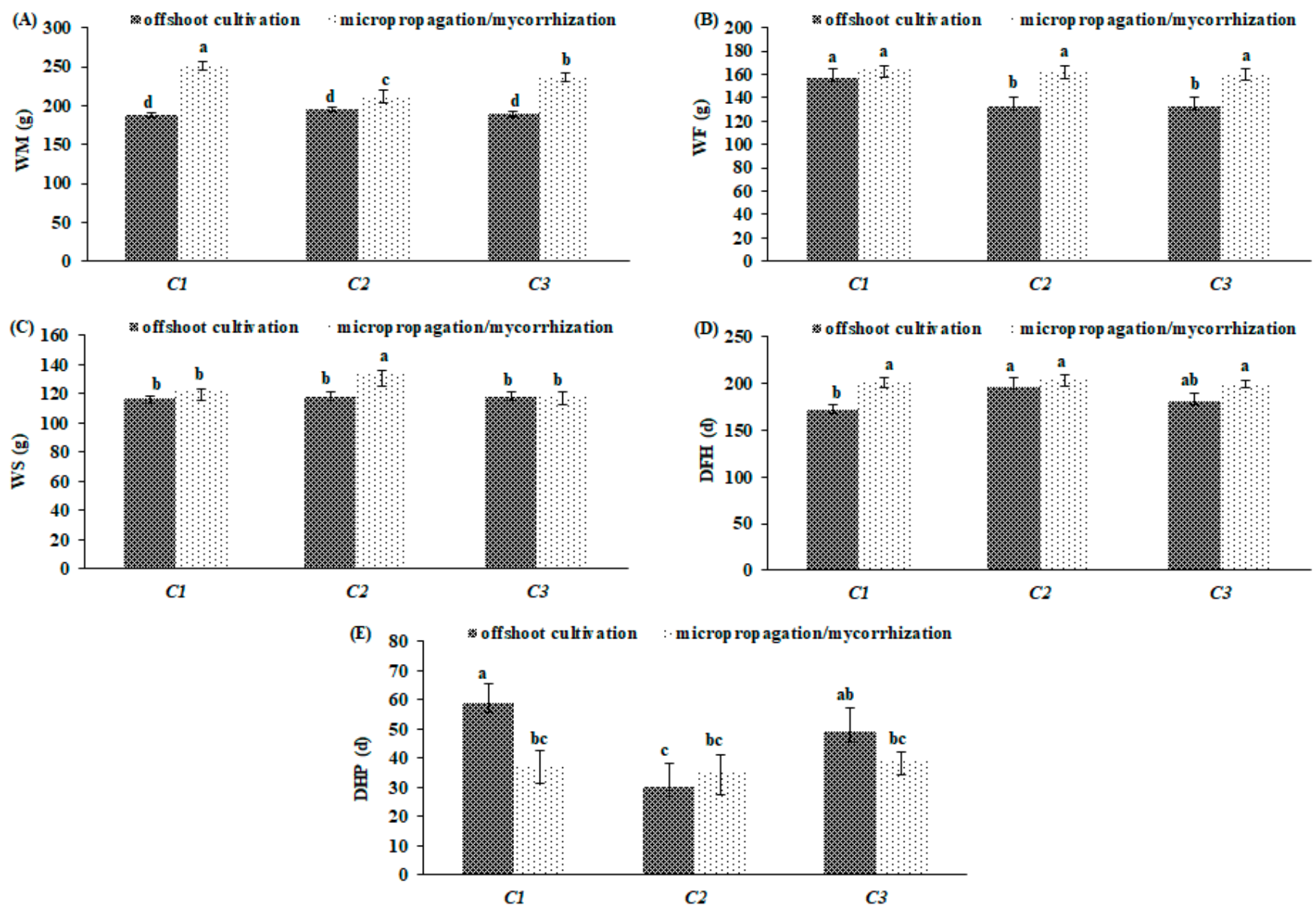

Figure 4. Bio-agronomical traits in clone of globe artichoke plants as affected by 'genotype $\times$ propagation method'. Different letters indicate significance at Fisher's protected LSD (least significant difference) test $(p \leq 0.05)$. Vertical bars indicate \pm standard deviation. WM, main head fresh weight (A); WF, first order head fresh weight (B); WS, second order head fresh weight (C); DFH, first harvest (D); DHP, harvest period (E).

As shown by the ANOVA, WF, WS, and NH were also associated with a significant 'propagation method $\times$ season' interaction (Table 1 ). Going from season I to season II, both offshoots cultivation and micropopagated/mycorrhized plants consistently increased their $\mathrm{NH}(+39$ and $+12 \%$, respectively) (Figure $3 \mathrm{~A}$ ). With reference to WF and WS, offshoots cultivated and micropopagated/mycorrhized plants exhibited a different behaviour. Passing from season I to season II, WF revealed significant differences only within offshoots cultivated plants. The same applied to the WS in the case of micropopagated/mycorrhized plants (Figure 5B,C). 

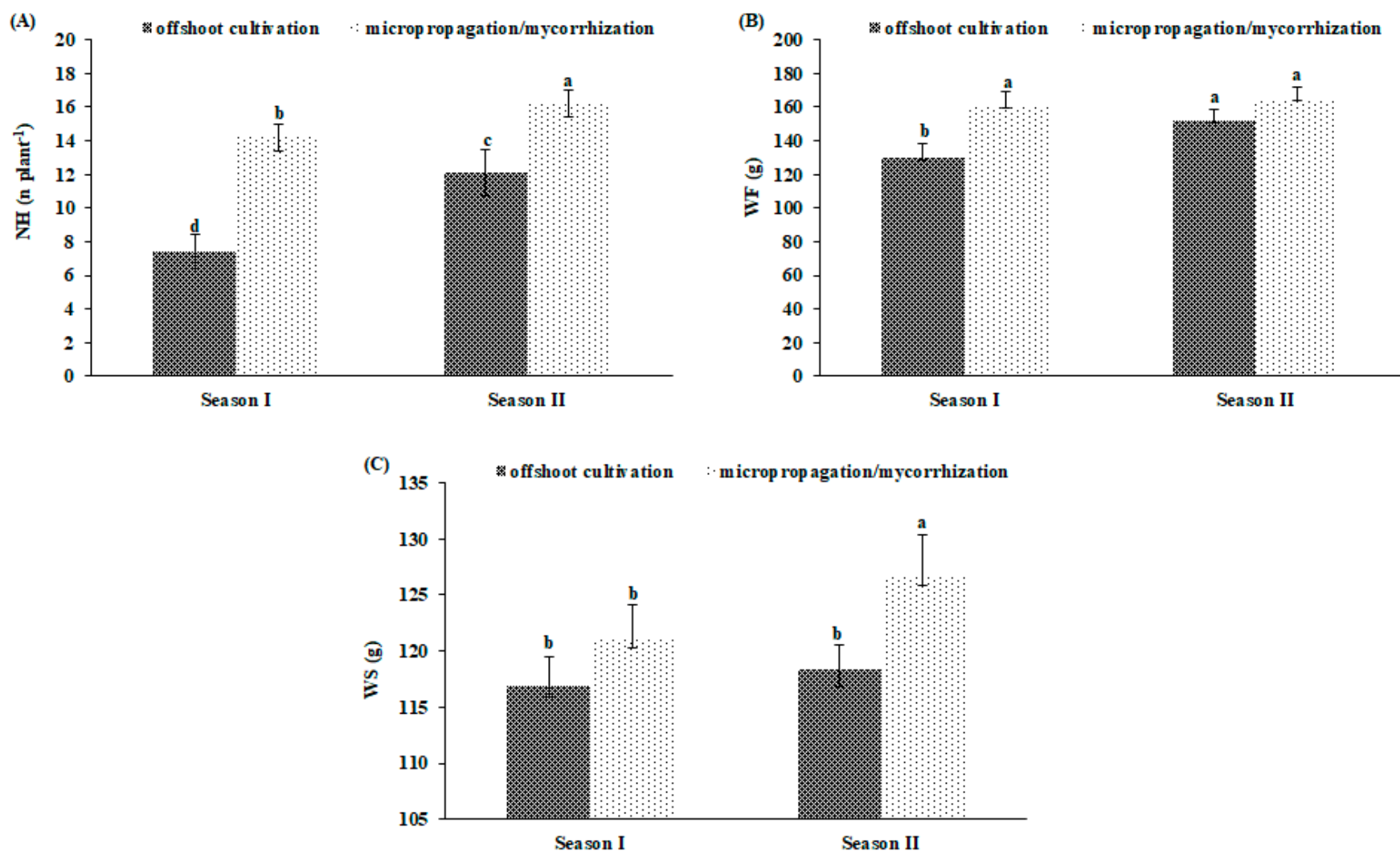

Figure 5. Bio-agronomical traits in clone of globe artichoke plants as affected by 'propagation method $\times$ season'. Different letters indicate significance at Fisher's protected LSD (least significant difference) test $(p \leq 0.05)$. Vertical bars indicate \pm standard deviation. $\mathrm{NH}$, number of heads (A); WF, first order head fresh weight (B); WS, second order head fresh weight (C).

\section{Discussion}

This study characterized some morphological and bio-agronomical traits in relation to two propagation methods (offshoots cultivation and micropopagated/mycorrhized plants) on three early globe artichoke clones of 'Violetto di Sicilia' over two growing seasons. The vegetative propagation, applied by local farmers over time on the autochthones landraces, favored the accumulation of mutations, which are considered to be the principal cause of uncertain yield performance. As suggested by Mauro et al. [9], the yield potential is the primary factor for the farmers' choice of globe artichoke genotype. In this paper, all of the selected micropopagated/mycorrhized clones yielded more than the offshoots cultivated ones, as well as a major NH. Analogous better yield performance was observed in a study conducted on micropropagated/mycorrhized plants of 'Violet de Provence', a reflowering globe artichoke genotype well-adapted in South Italy [30]. The positive response of both Y and $\mathrm{NH}$ suggests that the micropropagation, in conjunction with AMF application, could represent an effective cultivation system for obtaining high-productive plant material in open-field. Our hypothesis is corroborated by the effectiveness of the biotechnological protocol proposed by Campanelli et al. [18], where the production of globe artichoke plantlets was based on the micropropagation/mycorrhizal association. The micropropagation could ensure disease-free plantlets, mainly artichoke latent virus-free, which is considered to seriously compromise globe artichoke yield [32], while the inoculation of AMF offers several benefits to the host plant, such as drought and salinity tolerance, disease resistance, and improves nutrient and water uptake by a better development of the roots [33,34]. Such symbiotic interaction with the roots increases the ex-vitro survival of the microplants [35]. In addition, it was associated as a plant growth-promoting, as observed in previous works performed on both micropropagated and micropropagated/mycorrhized plants of globe artichoke $[18,36]$, as well as in other crops $[25,37]$. Positive effects were also observed in terms 
of polyphenols content profile, as it was established by some authors [30,38,39]. Pandino et al. [26] found that the micropropagation/mycorrhization appeared to give a higher content of caffeoylquinic acids in globe artichoke. Here, the micropropagated/mycorrhized plants of globe artichokes lead to the biggest structural changes in the leaves tissues, such as the length and width of longest lobe, consequently enhancing the physiological activities [40]. This had likely a direct bearing on all plant morphological traits under study (i.e., plant height, main floral stem length and diameter) and head fresh weight (WM, WF, WS, WT). As reported in other early globe artichoke genotypes [41,42], the micropropagated/mycorrhized plants accumulated almost a month late on the DFH and reduced its DHP with respect to those offshoots cultivated for nearly ten days. However, in the near future the reduced earliness of the micropropagated plants could be improved by the breeding work based on the identificatication of QTL for earliness in the globe artichoke [43]. These data were in disagreement with a similar study conducted by Ruta et al. [30], which did not find statistical differences among applied propagation methods. This discrepancy could be explained through the different genotypes and environments applied in the study, since the specificity of AMF-host plant relationship could have influenced the responses [44]. In the other hand, the present study has also shown that the 'propagation method $\times$ genotype' interaction was significant for seven out of the thirteen considered traits, including DHF and DHP. For example, between the micropropagated/mycorrhized and offshoots cultivated ' $\mathrm{C} 2$ ' there was no statistical difference observed for both the DFH and DHP, while the other traits were in favour to that micropropagated/mycorrhized. This result suggests that the micropropagated/mycorrhized ' $\mathrm{C} 2$ ' could represent promising and profitable material to provide to producers (since it had no significant loss of precocity, along with a better yield performance respect to that offshoots cultivated). In addition, in our previous work, performed in the same conditions, the micropropagated/mycorrhized ' $\mathrm{C} 2$ ' had the highest levels of caffeoylquinic acids, apigenin and its conjugated [26]. In this contest, our findings were in line with those of Ruta et al. [30], highlighting as the propagation method give back different performances in relation to the genotype. Other authors likewise confirmed the important role of the 'propagation method $\times$ genotype' interaction in terms of several of the physiological, morphological, and biochemical responses of other crops grown under field conditions [45-47]. Behind the genotype, the growing season might also have an effect on the responses of the propagation method, as revealed by the significant 'propagation method $\times$ growing season' interaction observed in this study on NH, WF and WS. These traits, along with DFH, DHP and Y, were also affected by the growing season, regardless of the propagation method and genotype. In particular, the above-mentioned traits were recovered higher in SII than in SI, except for the DFH. Some authors also ascribed the yield fluctuations of globe artichoke across growing seasons to the variability of weather conditions as major responsible [48,49].

\section{Conclusions}

To our knowledge, the current study reported, for the first time, the plant growth and productive traits of three micropropagated/mycorrhized early globe artichoke clones of 'Violetto di Sicilia', growing under field conditions. According to our data, the micropropagation/mycorrhization, as compared with vegetative propagation, had a positive effect on all undertaken morphological and bio-agronomical traits of all early globe artichokes except for the DFH. Nevertheless, the enhancement of both NH and Y might overcome the loss of precocity of micropropagated/mycorrhized plants. The effect was most pronounced in micropropagated/mycorrhized plants of ' $\mathrm{C} 2$ ', as indicated by the better yield performance and any statistical difference for both the DFH and DHP as compared to offshoots cultivated plants of ' $\mathrm{C} 2$ '. The likely genetic basis of this differential effect confirmed the importance of genetic background when dealing with the field management, as well as the fluctuations linked to growing seasons. Given the importance of this crop to the Mediterranean economy, it appeared that micropropagation/mycorrhization could represent a viable technique to provide to producers virus-free plantlets with high per- 
centage of survival after transplantation in open field conditions, while at the same time controlling genetic erosion of endangered landrace germplasm in a sustainable cropping system. It is reasonable that the wild parent should be selected for important traits such as yield performance, quality traits, tolerance to environmental stresses, and resistance to diseases and pests. Therefore, further research is needed to evaluate the consequences of micropropagation/mycorrhization on the field performance of other globe artichoke clones in order to develop a possible selection program to raise higher agronomic and biochemical performances of this autochthonous landrace.

Author Contributions: G.P.: writing original draft preparation, investigation, data curation; formal analysis; S.L.: writing-review and editing, investigation, data curation; formal analysis; L.M.A.: data curation, resources; C.R.: investigation; methodology; G.M.: conceptualization; supervision; writing-reviewing and editing. All authors have read and agreed to the published version of the manuscript.

Funding: This research received no external funding.

Institutional Review Board Statement: Not applicable for studies not involving humans or animals. Informed Consent Statement: Not applicable.

Data Availability Statement: Not applicable.

Conflicts of Interest: The authors declare no conflict of interest.

\section{References}

1. Mauromicale, G.; Pesce, G.R.; Curt, M.D.; Fernández, J.; González, J.; Gominho, G.; Tabla, R.; Roa, I.; Portis, E. Cynara cardunculus as a Multiuse Crop. In The Globe Artichoke Genome. Compendium of Plant Genomes; Portis, E., Acquadro, A., Lanteri, S., Eds.; Springer: Cham, Switzerland, 2019; pp. 65-98.

2. Dabbou, S.; Dabbou, S.; Pandino, G.; Lombardo, S.; Mauromicale, G.; Chahdoura, H.; Gasco, L.; Helal, A.N. In vitro antioxidant activities and phenolic content in crop residues of Tunisian globe artichoke. Sci. Hortic. 2015, 190, 128-136.

3. Lombardo, S.; Pandino, G.; Mauromicale, G. Minerals profile of two globe artichoke cultivars as affected by NPK fertilizer regimes. Food Res. Int. 2017, 100, 95-99. [CrossRef] [PubMed]

4. Scavo, A.; Pandino, G.; Restuccia, A.; Lombardo, S.; Pesce, G.R.; Mauromicale, G. Allelopathic potential of leaf aqueous extracts from Cynara cardunculus L. on the seedling growth of two cosmopolitan weed species. Ital. J. Agron. 2019, 14, 78-83. [CrossRef]

5. Lombardo, S.; Pandino, G.; Mauromicale, G. The influence of pre-harvest factors on the quality of globe artichoke. Sci. Hortic. 2018, 233, 479-490. [CrossRef]

6. Lombardo, S.; Restuccia, C.; Muratore, G.; Barbagallo, R.N.; Licciardello, F.; Pandino, G.; Scifò, G.O.; Mazzaglia, A.; Ragonese, F.; Mauromicale, G. Effect of nitrogen fertilisation on the overall quality of minimally processed globe artichoke heads. J. Sci. Food Agr. 2017, 97, 650-658. [CrossRef] [PubMed]

7. Portis, E.; Mauromicale, G.; Barchi, L.; Mauro, R.; Lanteri, S. Population structure and genetic variation in autochthonous globe artichoke germplasm from Sicily Island. Plant Sci. 2005, 168, 1591-1598. [CrossRef]

8. Costanzo, A.; Bàrberi, P. Functional agrobiodiversity and agroecosystem services in sustainable wheat production. A review. Agron. Sustain. Dev. 2014, 34, 327-348. [CrossRef]

9. Mauro, R.P.; Portis, E.; Lanteri, S.; Lo Monaco, A.; Mauromicale, G. Clonal selection in a globe artichoke landrace: Characterization of superior germplasm to improve cultivation in Mediterranean environments. J. Agric. Sci. 2015, 153, 102-113. [CrossRef]

10. Morone-Fortunato, I.; Ruta, C.; Castrignano, A.; Saccardo, F. The effect of mycorrhizal symbiosis on the development of micropropagated artichokes. Sci. Hortic. 2005, 106, 472-483. [CrossRef]

11. El Boullani, R.; Elmoslih, A.; El Finti, A.; El Mousadik, A.; Serghini, M.A. Improved in Vitro Micropropagation of Artichoke (Cynara Cardunculus var. scolymus L.). Eur. J. Sci. Res. 2012, 80, 430-436.

12. Barba, M.; Di Lernia, G.; Babes, G.; Citrulli, F. Produzione e conservazione di germoplasma di carciofo di tipo "Romanesco" esenti da virus. Italus Hortus 2004, 11, 5-10.

13. Papanice, M.A.; Cinquanta, A.; Bottalico, G.; Sumerano, P.; Gallitelli, G. Produzione di germoplasma risanato di carciofo brindisino. Italus Hortus 2004, 11, 11-15.

14. Rey, N.A.; Papacchioli, V.; Tavazza, R.; Pagnotta, M.A. Gauging the genetic changes occurring across globe artichoke micropropagation towards an appropriate variety registration and nursery production. Sci. Hortic. 2013, 156, 121-126. [CrossRef]

15. Pécaut, P.; Martin, F. Variation occurring after natural and in vitro multiplication of early Mediterranean varieties of globe artichoke (Cynara scolymus L.). Agronomie 1993, 13, 909-919. [CrossRef]

16. Kumar, K.; Rao, I.U. Morphophysiologicals problems in acclimatization of micropropagated plants in -ex vitro conditions-A reviews. J. Ornam. Hortic. 2012, 2, 271-278. 
17. Ruta, C.; Perrini, R.; Tagarelli, A.; Morone-Fortunato, I. Use of arbuscular mycorrhiza for acclimatization of micropropagated plantlets of melon, oregano, artichoke and Spanish broom. Acta Hortic. 2009, 812, 473-478. [CrossRef]

18. Campanelli, A.; Ruta, C.; Tagarelli, A.; Morone-Fortunato, I.; De Mastro, G. Effectiveness of mycorrhizal fungi on globe artichoke (Cynara cardunculus L. var. scolymus) micropropagation. J. Plant Interact. 2014, 9, 100-106. [CrossRef]

19. Gianinazzi, S.; Gollotte, A.; Binet, M.-N.; van Tuinen, D.; Redecker, D.; Wipf, D. Agroecology: The key role of arbuscular mycorrhizas in ecosystem services. Mycorrhiza 2010, 20, 519-530. [CrossRef] [PubMed]

20. Gosling, P.; Hodge, A.; Goodlass, G.; Bending, G.D. Arbuscular mycorrhizal fungi and organic farming. Agric. Ecosyst. Environ. 2006, 113, 17-35. [CrossRef]

21. Jeffries, P.; Gianinazzi, S.; Perotto, S.; Turnau, K.; Barea, J.-M. The contribution of arbuscular mycorrhizal fungi in sustainable maintenance of plant health and soil fertility. Biol. Fertil. Soils 2003, 37, 1-16. [CrossRef]

22. Pacifici, S.; Lucchesini, M.; Curadi, M.; Grainfenberg, A. Influence of medium composition and vessel ventilation during the micropropagation stages of Cynara scolymus L. cv. Grato 1. Adv. Hortic. Sci. 2007, 21, 83-88.

23. Bedini, L.; Lucchesini, M.; Bertozzi, F.; Graifenberg, A. Plant tissue cultures from four Tuscan globe artichoke cultivars. Cent. Eur. J. Biol. 2012, 7, 680-689. [CrossRef]

24. Rouphael, Y.; Franken, P.; Schneider, C.; Schwarz, D.; Giovannetti, M.; Agnolucci, M.; De Pascale, S.; Bonini, P.; Colla, G. Arbuscular mycorrhizal fungi act as biostimulants in horticultural crops. Sci. Hortic. 2015, 196, 91-108. [CrossRef]

25. Lombardo, S.; Abbate, C.; Pandino, G.; Parisi, B.; Scavo, A.; Mauromicale, G. Productive and physiological response of organic potato grown under highly calcareous soils to fertilization and mycorrhization management. Agronomy 2020, 10, 1200. [CrossRef]

26. Pandino, G.; Lombardo, S.; Lo Monaco, A.; Ruta, C.; Mauromicale, G. In vitro micropropagation and mycorrhizal treatment influences the polyphenols content profile of globe artichoke under field conditions. Food Res. Int. 2017, 99, 385-392. [CrossRef]

27. Murashige, T.; Skoog, R. A revised medium from rapid growth and bioassays with tobacco tissue culture. Physiol. Plant. 1962, 15, 473-497. [CrossRef]

28. Nitsch, J.P.; Nitsch, C. Haploid plants for pollen grains. Science 1969, 63, 85-87. [CrossRef]

29. Giovannetti, M.; Mosse, B. An evaluation of techniques for measuring vescicular arbuscular mycorrhizal infection in roots. New Phytol. 1980, 84, 489-500. [CrossRef]

30. Ruta, C.; Tagarelli, A.; Campanelli, A.; De Mastro, G. Field performance of micropropagated and mycorrhizal early globe artichoke plants. Eur. J. Agron. 2018, 99, 13-20. [CrossRef]

31. Bianco, V.V. Carciofo (Cynara scolymus). In Orticoltura; Bianco, V.V., Rimpini, F., Eds.; Patron Editore: Bologna, Italy, 1990; pp. 209-251.

32. Saccardo, F.; Micozzi, F.; Di Lernia, G.; Piccioni, C.; Barba, M.; Pagnotta, M.A. Virus-free artichoke germplasm: Quali-quantitative response of globe artichoke. Acta Hortic. 2007, 730, 375-379. [CrossRef]

33. Cruz, C.; Green, J.J.; Watson, C.A.; Wilson, F.; Martins-Loucão, M.A. Functional aspects of root architecture and mycorrhizal inoculation with respect to nutrient uptake capacity. Mycorrhiza 2004, 14, 177-184. [CrossRef]

34. Smith, S.E.; Read, D.J. Mycorrhizal Symbiosis; Academic Press: Cambridge, UK, 2008.

35. Apóstolo, N.M.; Brutti, C.B.; Llorente, B.E. Leaf anatomy of Cynara scolymus L. in successive micropropagation stages. In Vitro Cell. Dev. Biol. Plant 2005, 41,307-313. [CrossRef]

36. Ancona, S.; De Mastro, G.; Jenderek, M.M.; Ruta, C. Micropropagation supports reintroduction of an apulian artichoke landrace in sustainable cropping systems. Agronomy 2021, 11, 1169. [CrossRef]

37. Kavatagi, P.K.; Lakshman, H.C. Interaction between AMF and plant growth-promoting rhizobacteria on two varities of Solanum lycopersicum L. World Appl. Sci. J. 2014, 32, 2054-2062.

38. Ceccarelli, N.; Curadi, M.; Martelloni, L.; Sbrana, C.; Picciarelli, P.; Giovannetti, M. Mycorrhizal colonization impacts on phenolic content and antioxidant properties of artichoke leaves and flower heads two years after field transplant. Plant Soil 2010, 335, 311-323. [CrossRef]

39. Sbrana, C.; Avio, L.; Giovannetti, M. Beneficial mycorrhizal symbionts affecting the production of health-promoting phytochemicals. Electrophoresis 2014, 35, 1535-1546. [CrossRef] [PubMed]

40. Krishna, H.; Singh, S.K.; Sharma, R.R.; Khawale, R.N.; Grover, M.; Patel, V.B. Biochemical changes in micropropagated grape (Vitis vinifera L.) plantlets due to arbuscular-mycorrhizal fungi (AMF) inoculation during ex vitro acclimatization. Sci. Hortic. 2005, 106, 554-567. [CrossRef]

41. Pécaut, P.; Martin, F. Non-conformity of in vitro propagated plants of early Mediterranean varieties of globe artichoke (Cynara scolymus L). Acta Hortic. 1992, 300, 363-366. [CrossRef]

42. Tavazza, R.; Papacchioli, V.; Ancora, G. An improved medium for in vitro propagation of globe artichoke (Cynara scolymus L.) cv. Acta Hortic. 2004, 660, 91-97. [CrossRef]

43. Portis, E.; Scaglione, D.; Acquadro, A.; Mauromicale, G.; Mauro, R.; Knapp, S.J.; Lanteri, S. Genetic mapping and identification of QTL for earliness in the globe artichoke/cultivated cardoon complex. BMC Res. Notes 2012, 5, 252. [CrossRef]

44. Lombardo, S.; Scavo, A.; Abbate, C.; Pandino, G.; Parisi, B.; Mauromicale, G. Mycorrhizal inoculation improves mineral content of organic potatoes grown under calcareous soil. Agriculture 2021, 11, 333. [CrossRef]

45. Gopal, J.; Minocha, J.L.; Sidhu, J.S. Comparative performance of potato crops raised from microtubers induced in the dark versus microtubers induced in light. Potato Res. 1997, 40, 407-412. [CrossRef] 
46. Jamieson, A.R.; Nickerson, N.L. Field performance of the lowbush blueberry propagated by seed, stem cuttings and micropropagation. Acta Hortic. 2003, 626, 423-428. [CrossRef]

47. Oggema, J.N.; Kinyua, M.G.; Ouma, J.P.; Owuoche, J.O. Agronomic performance of locally adapted sweet potato (Ipomoea batatas (L) Lam.) cultivars derived from tissue culture regenerated plants. Afr. J. Biotechnol. 2007, 6, $1418-1425$.

48. Ledda, L.; Mameli, M.G.; Milia, M.; Marras, G.F. Influence of plant shading and ovoli typology on globe artichoke development, early production and head atrophy: Preliminary results. Acta Hortic. 2003, 660, 365-371. [CrossRef]

49. Deligios, P.A.; Tiloca, M.T.; Sulas, L.; Buffa, M.; Caraffini, S.; Doro, L.; Sanna, G.; Spanu, E.; Spissu, E.; Urracci, G.R.; et al. Stable nutrient flows in sustainable and alternative cropping systems of globe artichoke. Agron. Sustain. Dev. 2017, 37, 54. [CrossRef] 